\title{
Acknowledgment of Country: Intersecting Australian Pentecostalisms Reembeding Spirit in Place
}

\author{
Tanya Riches ${ }^{1,2}$ (D) \\ 1 The Edward Cadbury Centre for the Public Understanding of Religion, University of Birmingham, \\ Edgbaston, Birmingham B15 2TT, UK \\ 2 Hillsong College, 1-9 Solent Circuit, Norwest, NSW 2153, Australia; tanya.riches@hillsong.com
}

Received: 7 August 2018; Accepted: 7 September 2018; Published: 21 September 2018

\begin{abstract}
This article builds upon a previous application of Nimi Wariboko's "Charismatic City" proposal, adapting it to the Australian context. Within this metaphor, the Pentecostal worshipper is situated in a rhizomatic network that flows with particular energies, forming a new spirit-ed common space that serves as the basis of global civil society. In this network, the culturally dominant metropolis and the culturally alternative heteropolis speak in distinct voices or tongues: An act that identifies and attunes participants to the Spirit's existing work in the world. Here, two interweaving Australian Pentecostalisms are presented. The metropolis in this example is Hillsong Church, well known for its song repertoire and international conferences. In contrast, the heteropolis is a diverse group led by Aboriginal Australian pastors Will and Sandra Dumas from Ganggalah Church. In 2017, Hillsong Conference incorporated a Christianised version of an "Acknowledgement to Country," a traditional Indigenous ceremonial welcome, into its public liturgy, which is arguably evidence of speaking new languages. In this case, it also serves a political purpose, to recognise Aboriginal Pentecostals within a new commons. This interaction shows how Joel Robbin's Pentecostal "impulses" of "globalization," "cultural fragmentation" and "world-making" can operate simultaneously within the ritual life of national churches.
\end{abstract}

Keywords: Pentecostalism; Hillsong; Aboriginal Australian; Charismatic City; Acknowledgement of Country; Globalization

Pentecostalism heralded an unprecedented change to the Christian religion. Thus, Cox (2013, p. 116) epitomises Pentecostalism as a "mood," an "... [oceanic] feeling in the pit of the cultural gut that a very big change is under way." Today, NeoPentecostalism is characterised within the literature as having spiritual and moral potency for an adherent's negotiation of (as in, both resisting and adapting to) the effects of modernity and globalization (Marshall-Fratani 1998; Gifford 2004, 2015; Porter 2017; Jennings 2017). NeoPentecostal megachurches produce cultural and artistic products that hold great narrative power, the distribution of which forces them to engage with their external contexts (Piot 2012; Myers 2015). This article suggests that even as Pentecostals resist and incorporate the world around them, distributing their resources to various markets, such interactions cause their own social relations to change. In particular, it reviews interaction between two Pentecostalisms in the Australian context, with the resulting attempt to embed the universal global liturgical practices into land or "country." Within Aboriginal Australian culture, "country" is a concept that encompasses physical ecology but also includes the experience (and harmony) of the people living in the land. For most Aboriginal people, "country" imparts an experience of the divine or transcendent. This case study perhaps points to the future trajectories of Pentecostal communities and their theologies, and therefore the contribution of their social relations to the wider world.

The central question of this paper is, "what is the nature of the church's social engagement in changing global/national political environments, and, most importantly, how are NeoPentecostal 
forms changed by their interactions?" Focusing on one example, the influential megachurch Hillsong, the thesis of this paper is that the slow transformation of Australian Pentecostal worship practice is reframing worshipers' understandings of the Spirit's work inside space and place, and is thus contributing spiritual and moral imperative to a new national narrative that includes those Australian cultures most marginalised by former theologies of expansion and colonialism, i.e., Australia's Aboriginal and Torres Strait Islander peoples.

\section{Methodology}

This article contextualises these events within a burgeoning literature of global Pentecostalism, but particularly within ethnographic studies presented by anthropologists of Christianity, including Robbins (2010), who identifies Pentecostalism's simultaneous "impulses" of cultural homogenization, fragmentation, and revitalization. To explain this paradox further, the article draws upon a metaphor developed by Nigerian Pentecostal scholar Nimi Wariboko in his book The Charismatic City and the Public Resurgence of Religion (Wariboko 2014). Within it, he identifies Pentecostalism as a rhizomic network, meaning "both a metropolis (mother city) and a heteropolis (an other, alternative polis) that is operating in, through, and energising global cities" (Wariboko 2014, p. 26). From this, the article then identifies two interacting Australian Pentecostalisms and notes recent developments at the Sydney campuses of the megachurch Hillsong Church to consider the incorporation of a Western Christianised appropriation of the Aboriginal Australian Dreaming ceremonial "Acknowledgment of Country" into Hillsong's largest conferences. Arguing that this can be read as an instance of the dominant Australian Pentecostal group learning to speak in new tongues, ${ }^{1}$ it outlines the interaction between the dominant culture and marginalised Australian Pentecostal groups that preceded and followed this ritual adaptation in Australia's premier Pentecostal urban conferences. ${ }^{2}$ Although a comparison of Indigenous and non-Indigenous Australian Pentecostalisms has been previously attempted (See Riches 2016), the intersection of Australian Pentecostalisms has to date been little explored. Finally, extending Wariboko's work, the article suggests that this incorporation is perhaps evidence of the development of a new spiritual polis from which a new type of Australian civil community can be born, and is thus an example of Pentecostal "world making," consistent with the distinct "Pentecostal social imaginary" promoted by J.K.A. Smith (2010, p. 11) or the "pneumatological imagination" identified by Amos Yong (2000, p. 179).

This case study provides a local example of how ritual change occurs, with content relevant to the national Australian context, by highlighting key moments of Pentecostal worship practices found within both the historical literature and my own ethnographic study in both Indigenous and non-Indigenous Australian Pentecostal churches. The insights arose primarily from continuing resonances between the fieldwork data collected for my MPhil (which involved a review of ten years of Hillsong music at Melbourne's Australian Catholic University) and fieldwork conducted in three urban Aboriginal-led congregations for my PhD (at Fuller Theological Seminary). This research found that Aboriginal Australian-led Pentecostal congregations utilised a multiplicity of methods to negotiate globalization; however, by emphasising material production, the leaders were seeking to revitalise (often misunderstood) "pre-modern" spiritualities and relational positionalities. This information was supplemented by mining social media discussions in which friends and acquaintances outlined their responses to the "Acknowledgement of Country" event that took place at Hillsong Conference in 2017. The short comments, here construed as statements, reveal the opinions of some who attended this

1 Here the intention is not to argue that such speech-acts are replacing the doctrinally unique glossolalic and xenolalic practices, which continue in other contexts of the church.

2 This article draws upon Richard Trugden's well known volume Why Warriors Lay Down and Die (Trudgen 2000), which contrasts Australian "dominant culture" (meaning Settler or Western culture) against diverse Aboriginal cultures (such as Yolngu) on Australia's mainland. The Yongu Elders are marginalised within public discourse. Thus, the diverse first nations provide alternative Australian societies which are at times in opposition to the state. 
event as well as those who heard about it afterwards. But before moving on, this event will now be situated in relation to the literature. ${ }^{3}$

\section{Global Pentecostalism and Its Impulses}

From the opening of the twentieth century, Pentecostalism has grown exponentially, with many scholars claiming 600 million adherents, sometimes separated into discrete "waves" linked by "family resemblances." This draws upon Allan Anderson's famous definition of "Pentecostalism(s)" as "churches with a family resemblance that emphasise the working of the Holy Spirit, sharing common experience of the Spirit and practice of spiritual gifts" (Anderson 2010, p. 157; 2013, p. 5) Notably, the historicity of these waves is disputed by historian Mark Hutchinson (2017). Nevertheless, Anderson's framework remains useful as a rough means to distinguish these communities by worship practice, a topic of Pentecostal scholarship which has only recently emerged. Therefore, while "Classical" Pentecostals place great emphasis on their denomination's normative social rules (e.g., prohibitions on drinking and smoking) and may practice tongues on a regular basis, the "Charismatic" churches, in contrast, often continue to worship in their own denominations (with traditional liturgies) and therefore tend to cultivate a fusion of practice in which the gifts of the Spirit "break in" to or occasionally disrupt more traditional worship forms. ${ }^{4}$ This can be distinguished from the "Older Independent" or mission churches in Africa and China, who may have borrowed "the practices of prayer, healing, and spiritual gifts" but perhaps not the Pentecostal label (Anderson 2010, p. 5). Finally, NeoPentecostals are considered a diverse group that includes many of the world's megachurches, who share an identity that often crosses denominational lines. The main commonality of this group is that the authority for local worship practices lies with the church leadership, who often follow global trends rather than Pentecostal or liturgical traditions. This characteristic leads Poloma and Green (2010) to identify them more generically as "Evangelical."

While the historical debates continue, it is arguably ethnographic studies of ritual that have led to significant breakthroughs in understanding the Pentecostal movement's interaction with its world. For example, from his work with the Urapmin in Papua New Guinea, Joel Robbins (2010) proposes three common "impulses" of Pentecostalism, entitled "world-breaking," "world-making," and "globalization," which he claims structure the worship and other activities of most Pentecostal churches. These impulses are undergirded by powerful rituals that ensure that the movement delivers on its promises. The first stated impulse, "globalization," is debatably best described as a reordering of the spatial organization of social relations with greater "extensity, intensity, velocity and impact" (Held et al. 1999, p. 16). The second impulse of Pentecostalism, "world-breaking," involves its propensity to encourage "rupture" with indigenous rituals (Dombrowski 2001, 2002). ${ }^{5}$ Thus, the spread of Pentecostal practice is sometimes considered emblematic of Western hegemony (Yong 2015, p. 287). However, the third feature identified by Robbins is Pentecostalism's "world-making" impulse. This allows for cultures to adopt and transform Pentecostal practice-not only its forms, but also its processes (Meyer 2003, 2009, 2010). How scholars deem the forces of cultural homogenization and cultural fragmentation to be operating concurrently is of interest to this paper.

As for the broader claim, there is little doubt that ritual has contributed to Pentecostalism's extraordinary global expansion. Pentecostal experience is facilitated by the communal, oral, and affective practices of the Pentecostal churches (Chesnut 1997; Albrecht 1999; Coleman 2000; Maxwell 2005). A worshipper's knowledge of the Spirit is formed largely in real time and place,

3 All participants whose comments appear in this paper gave their consent for the content (and their name where relevant) to appear in writing.

4 Here Anderson cites "Catholic, Anglican, Orthodox, and various Protestant Charismatics" and notes that they "sometimes approach the subject of Spirit baptism and spiritual gifts from a sacramental perspective" (Anderson 2013, p. 6).

5 Here Robbins (2010) outlines the Urapmin's destruction of their cultural artifacts and practices such as gender segregation, which were justified by Pentecostal theologies generated in worship. 
with a particular group of people whose bodies become "entrained," moving dynamically to shout or whisper in synchronicity together (Marti 2012; Myrick 2017). Thus, Pentecostal theologians cite as their movements' central motif the biblical narrative of Acts 2, in which the diverse believers gathered in Jerusalem (Solivan 1998; Cartledge 2006; Yong 2013). Within this original Pentecost event, "tongues of fire" were said to rest on each worshipper's head, with the sign of "glossolalia," or heavenly languages, following, thus marking the age of the Spirit and the inauguration of the church. Frank Macchia (1993) outlines the retrieval of this practice via the continuing importance of tongues for Pentecostals as a sacrament, a sign of God's unmediated presence that empowers the believer for Christian life and witness. Speaking in tongues quickly became a distinctive practice of Pentecostal churches, accompanied by other ecstatic experiences in worship and prayer (Lovett [1975] 2015; Hummel 1978; Synan 1993). For James Smith (2010, p. 123), this practice or speech act ultimately produces a new social imaginary, as "tongues-speech is the language of communities of resistance who seek to defy the powers that be."

Charismatic Anglican Mark Cartledge (2006) argues that the Pentecost event provides both "process" and "framework" for the diverse global movement's spirituality. As an oral community, the process of theologising continues within each worship event or public gathering. In this way, the revivals of the 1970s were characterised as a return to the biblical text via continuing this oral practice, rather than a deviance from the various denominations' traditions (Marshall 1977; Hummel 1978). This logic has arguably informed the global NeoPentecostal worship service as found in urban cities today, with a focus upon shared techne or practice, e.g., iconic symbols of embodied postures such as raised hands, a five-piece rock band, and flashing lights (Coleman 2000; Farhadian 2007; Hutchinson 2013). Such practices are easily translatable, meaning that they move across state borders and are constantly updated (Csordas 1992, 2007). Thus, Asian American scholar Amos Yong proposes that the Pentecostal "framework" or "pneumatological imagination" is a multifarious global theology formed out of this common experience of the Spirit (Yong 2000, p. 179). In this way, Pentecostalism is diverse but unified.

The case study presented in this article demonstrates how Pentecostalism transforms as it moves through time and space. Rather than viewing Pentecostalism in isolation, this article suggests that it is through the interaction of diversity and unity that Pentecostals are forging a language of Spirit empowerment and are speaking in new languages that identify and attune participants to the Spirit's work in the world - a feature which has special relevance in a new era of urban megacities and cyber space. These interactions will be examined further using Nimi Wariboko's proposal in The Charismatic City, which is then applied in an Australian context.

\section{Nimi Wariboko's Proposal}

In his book The Charismatic City and the Public Resurgence of Religion, Nimi Wariboko (2014, p. xii) describes Pentecostalism today as a rhizomatic network which is "both a metropolis (mother city) and a heteropolis (other, alternative city) that is operating in, through, and energizing global cities." 6 In summary, for Wariboko, Pentecostalism historically developed via three philosophies reminiscent of distinct cities: The Sacred, the Secular and the Charismatic. To form an understanding of the metropolis, Wariboko draws upon Western medieval European religious systems in which the king's body and land were entwined. Thus, Augustine's City of God, later embodied as "Christendom," became a place of intensified divine presence. All were conscious that "God is here" (Wariboko 2014, p. 99). From this city, Wariboko notes, "the task of believers' public engagement ... [was] to sing their song well enough that the society at large [was] brought to their truth claim" (Wariboko 2014, p. 99). However, Wariboko notes the subsequent emergence of a "Secular City" in which God was proclaimed dead (Cox 2013;

6 Wariboko presents three distinct philosophies of pneumatologically-oriented social engagement that exist simultaneously but also offer progression (See Riches (2016) for a more theological application of this theory). 
Wariboko 2014). There, all space was open as even "God comes from elsewhere" (Wariboko 2014, p. 100). Wariboko (2014, p. 94) asks, did the Spirit in fact move humanity towards the Secular City? If so, what was God's mission? His controversial answer is the decentralisation of religion, which ended an elite system of priests which dissuaded converts from participation and responsibility in the polis. Within the third "Charismatic City," however, divine presence again permeates all space and all time. There is no absence of God. This is through a process of the transformation of space as the Spirit enfolds, then unfolds and refolds everything (Wariboko 2014, p. 104). As Wariboko (2014, p. 100) says, "God is in you, but God overflows and connects you to the elsewhere and to the other." This re-enchanted "New Jerusalem," he claims, is a "network of networks" flowing from "London to Buenos Aires, from New York to New Delhi, and Rome to Lagos" (Wariboko 2014, p. 1).

This Pentecostal city has no border but intersects both the real and technological worlds (Wariboko 2014, p. 87). All are authorised and empowered with new identities carved out of the many nations and tribes (Wariboko 2014, p. 59). In this way, tongues overturns traditionalism (Wariboko 2014, p. 63). This marks the new "litourgeia," or work of the people. In this city, worship is clearly political as it is done in public, or in the shared "in-between space," and this forms a new commons of sorts and the basis of a global civil society (Wariboko 2014, pp. 45, 49, 53). Therefore, the Charismatic City acts to promote freedom and to remove unfreedom, allowing every citizen's potential to be actualised. Christians speak with their "others" in the public square, embracing and celebrating each contribution in pursuit of common good and peace-building (Wariboko 2014, p. 97). Pentecostal practice becomes a site of intense human activity, which forms a type of "commons" or new place between believers, representing the (often unconscious) bodily entrainment and shared "emotional energy" achieved through ritual focus that links the individual to the body politic, since " ... to participate in or enact a practice, is to exercise power, the power of being, the power to perform" (Wariboko 2014, p. 128). However, the city itself is made up of both the dominant (metropolis) and marginalised (heteropolis) identities which continue to work upon each other, conflicting with and transforming each other. He explains this as dynamic social practice. This article investigates evidence of new Pentecostal spiritualities or speech acts of this kind which are transforming the Pentecostal "social imaginary" in the local context of Australia.

\section{Hillsong as Metropolis}

The largest of the Australian megachurches is undoubtedly Hillsong Church. Founded in 1983, its extraordinary growth and influence via music has been well documented (Connell 2005; Wade and Hynes 2013; Riches and Wagner 2017; Marti 2017). Due in part to its now global prominence, researchers note that Hillsong transcends nationality and ethnicity, allowing its diverse adherents to intuitively feel at home in its worship setting regardless of their geographic location-thus promoting a certain "cosmopolitanism" (Riches and Wagner 2017; Porter 2017, 2018). The "uneven co-configurations of imaginaries of the 'local' and 'global'" are noted by Lena Rose (2018, p. 2) for example, who examines a negative interaction with the guest MC at a Hillsong United concert who amplified American Zionist theologies which conflicted with the expectations of the marginalised local Palestinian audience. In this way, Rose notes the impact of problematic interactions that occur within transnational space (in this instance, while overseas on a music tour). However, in contrast, this article notes the ways in which Hillsong (as metropolis) has at its centre begun to embed into land or "country" via encounter with Aboriginal Pentecostalism (as heteropolis) within its core, resulting in a visibility that allows the pursuit of a common life. This suggests a way that multiple "impulses" or even realities may be sustained within Pentecostalism globally.

Today, Hillsong Church gathers over 40,000 worshippers across its 30 locations, which meet regularly in 89 services. The congregation began as "Hills Christian Life Centre," a small church planted in 1983 in the suburban Hills District of Sydney by two ministers, Brian and Bobbie Houston, affiliated with the Australian Christian Churches (formerly known as the Assemblies of God in Australia) (Connell 2005; McIntyre 2007). Its music became so successful that the church rebranded 
to use its publishing name, "Hillsong," thus entrenching its geographic origins (the Hills District) and "song" as its two immutable symbols (Riches and Wagner 2012, 2017). Hillsong's contemporary choruses are now considered iconic (Riches 2010a, 2010b; Riches and Wagner 2012, 2017). Its annual calendar is punctuated by conferences, events and CD/book releases, which facilitate the distribution of its "resources" produced for other churches. Thus, Musicologist Mark Evans (2006, p. 77) states,

There would be few churches in Australia, of any denomination or persuasion, unaffected by the music of Hillsong Music Australia (HMA). Though some Christians told me they would never set foot in Hillsong Church due to theological differences, they were more than happy to sing music written and produced there.

In the early years, Hillsong often entreated the Spirit to descend upon the Australian landscape, sacralising hearts, bodies and this space the worshippers inhabited (Riches 2010b, p. 13). As this music was distributed in the UK and North American churches, it began to be used as evidence that God was moving even in the "outermost parts of the earth" (Acts 1:8), a metaphor for reverse mission back to the centre of Christendom. There was a clear shift in the church's imagination to extend their geographical borders beyond Sydney and towards the world (Riches and Wagner 2012; Evans 2015). Much of the local content was steadily replaced by more global lyrics and imagery (Riches and Wagner 2012). Once Darlene Zschech assumed the role of lead worship pastor, Hillsong's songs largely dispensed with the petition "Holy Spirit, come." Instead, songwriters reinforced the idea that God was always present, even when seemingly absent in a post-9/11 world. ${ }^{7}$ Arguably, however, the main purpose for Hillsong's music-making prevailed, which was the reconstruction of the Australian church as a central social institution. In this endeavour, the congregation actively participated, discerning God's supernatural anointing upon aspects of the worship service and energising these expressions. This could be measured in two ways: Physical participation in the worship event, and sales of the music (Riches 2010b, p. 50). Today, few Australians doubt that Hillsong is the dominant expression of contemporary Christianity in the nation. However, within the church itself, talk of God has expanded from reproducing its distinct practices towards developing language appropriate for the commons, or urban polis. Notions of Spirit absence have been replaced with immanence-God is everywhere, both in and outside of the church (See Riches (2016) for lyrical examples of this transition).

\section{Aboriginal Pentecostalism as Heteropolis}

According to the Australian Bureau of Statistics (2011), only around 1\% of Aboriginal people practice "traditional religion," while $73 \%$ of Indigenous Australians self-identify as Christian (Australian Bureau of Statistics 2006). ${ }^{8}$ Of these, $2.7 \%$ of Aboriginal people identify as Pentecostal, double the statistic for the wider population. In fact, Aboriginal Pentecostals seem to have used this religious form from the 1920s (Calley 1955; Calley and Reay 1964; Ono 2011, 2012), or even earlier. Malcolm Calley's ethnographic research took place during official racial segregation, which was maintained until Aboriginal peoples received citizenship in the 1960s. In his writings, Calley (1955, p. 11) argued that the rural East coast Australian towns at the time represented conflict between two spiritually charged and spatially distinct Australian religious ritual systems: The "old rule" of "the Dreaming," which he juxtaposed to an organised Christian religion of "the Trinity." He noted that the Bundjalung peoples had the Dreaming bora rings (or circles) for dancing (or "corroboree") ceremonies, with their initiated marugan or "clever men" who curated the sacred land sites. He contrasted this with local white congregations who gathered to sing hymns and listen to the "dogma" of their male clergy in Christian liturgy. They boasted similarly "righteous" or "authorized" men who curated mission outposts. Although he states, "The clever men are all dead," their power apparently lived on

7 This is explored further in Riches (2016), the precursor work to this article, which uses Wariboko's Charismatic City proposal to compare distinct Australian Pentecostalisms.

8 This rises to $6 \%$ in remote rural areas, but for the purposes of contrast no measure of Pentecostalism exists. 
within the minds of the white clergy, who placed embargoes on "drinking, smoking and clever men," depicted as " ... black powers of darkness, a rival force" (Calley 1955, p. 49).

Calley notes the effects of the religious segregation experienced by "mixed blood" Bundjalung living on the East Coast. Australia's missionaries and white congregations excluded them through "a feeling of unwelcome" that exacerbated their wider social marginalisation. Intriguingly, he describes a process by which a group of Bundjalung Pentecostals defied these traditionally accepted dichotomies by creating new religious space. He declares,

Aboriginal Pentecostalism is not merely a welding of Christianity onto a mixed blood community. It is an integration of a new religion into the social framework of the old ... the new religion, like the old, is partly magical and aspects of both the indigenous and alien cultures has been verified. (Calley 1955, pp. 4, 47)

More recently, Ono $(2011,2012)$ returned to these Bundjalung churches with Calley's printed photographs to reconstruct an oral history of these congregations. Her conclusion was that even today, many aspects of the Dreaming remained.

Today, Aboriginal Pentecostalism constitutes a series of overlapping networks that stretch across the nation (Riches 2017), though Aboriginal communities' relationship with both traditional churches and the state continues to be fraught. However, many Aboriginal Pentecostals living in the now more urbanised Bundjalung lands would reject claims of religious syncretism, and disagree that the Dreaming plays any part in their Aboriginal Pentecostal worship. Many prefer to denote the Dreaming as "spirituality" rather than "religion"—amidst claims that Dreaming was always a heterodox community of practice and belief (Grieves 2008). This is often simply termed "culture." Although some still associate Australian national identity with Christianity, there is increasing pressure to include Australia's original religiosity in state rituals, often reified for a late modern consumer society. Thus, the spirituality of "The Dreaming" or "Dreamtime" has become significant even in urban areas (Grieves 2009, p. 111). Of the rituals that exist, the most commonly used is the official "Welcome of Country" in which Elders welcome visitors onto land. Culturally appropriate welcomes are now staged at the beginning of every local, state and federal Australian government meeting as well as in many other institutions (Everett 2009). Thus, at state functions today, a ceremonial introduction is performed by an Elder. An Elder is a representative of the traditional owners of the land, meaning that they play an ongoing leadership role in the "country" on which the welcome is held. Or, where no Elder can be found, an adapted "Acknowledgement of Country" may be performed. An Acknowledgement may be spoken by anyone, and usually follows a pattern similar to the following: "I would like to acknowledge that we are gathered today on the land of the [insert nation] peoples, and to pay my respects to the Elders past and present." Both of these ceremonies perform (and sustain) a particular relationship to "country" for Australia's Aboriginal peoples, and are therefore significant to the continuation of these cultures. In recent years, Elders have taken a greater role in all of Australia's national holidays and public events.

Aboriginal ceremony is noted to hold complex meaning when performed in the urban space (Magowan 2000) but particularly also when performed by the state. In addition to welcome rituals, smoking ceremonies are featured at certain events, for example, as Akehurst (2012) notes incredulously, at the opening of the CSIRO, Australia's leading government agency for scientific research. But although welcome ceremonies are now generally deemed acceptable to the majority of Aboriginal Christians, smoking ceremonies can be divisive, with mixed reception by urban evangelical/Pentecostal Christians (Riches 2014, p. 28). This is likely due to associations with ancestor worship and the invoking of spirits. Rather than grapple with these complexities, most urban Christians (and their affiliated institutions, e.g., churches and schools) refuse to adopt all ceremonial practices, despite calls to do so by figures such as the late missiologist Langmead $(2002,2007)$. In this way, the evangelical/Pentecostal Australian church now often stands opposed to the everyday spirituality of 
its state. Despite this, many Aboriginal people identify both with institutional Christianity and culture. ${ }^{9}$ It is important to note that local Aboriginal spiritualities have been obscured by these and many other revisions. For example, Durkheim (1912) famously noted a particular "collective effervescence" within Australian Aboriginal Dreaming rituals as recorded by early colonists. While he never visited Australia to observe the spiritualty of Aboriginal peoples, scholars still draw upon his and Randall Collins's later theories to successfully describe the affective energies that power Pentecostal ritual and form its institutions (Collins 2004; Robbins 2010; Wariboko 2014).

The continuing vitality of Aboriginal Pentecostals and their contribution to this discussion have largely been ignored. Aboriginal Pentecostal leaders affirm Spirit as present in the world, utilising the ancient resources of Dreamtime cultural and religious practices to draw Australian's chaotic contemporary virtual life back into real time and place. For example, Birripi man Pastor William Dumas and his Bundjalung wife, Sandra Dumas, oversee Ganggalah Church. Will grew up in Sydney's urban suburbs, while Sandra is local to the area. Their diverse congregation draws on wisdoms of both Pentecostal and Indigenous cultures. In interviews, many of Ganggalah's members mentioned traditional "Welcome to Country" ceremonies as a practice compatible with Christianity. They promote this alongside sharing, hospitality, and caring for kin. Ganggalah Church regularly performs a traditional welcome honouring the land and Elders each time guests arrive into the city. But some older Aboriginal Pentecostals, such as Aunty Amelia Watego, were careful to qualify this as a "Christian welcome": 10

If a white person said, "Amelia is your church an Aboriginal church?" I wouldn't get offended-you know what I used to say? I used to say, "No, I tell the Lord it's his church, not our church." I said, "He could bring whoever he wants there" ... [W] used to always sing this song when visitors came... (sings) "There's a welcome here. There's a welcome here. There's a Christian welcome here."

These Pentecostals noted in interviews that white Australian pastors often rejected or blatantly ignored the Aboriginal community's requests for basic cultural recognition, citing their refusal to perform even a ceremonial "Acknowledgement to Country" to honour the traditional landowners. Many were confused by the fact that, although every Australian school and government meeting acknowledged Aboriginal Elders, they were often left unacknowledged (and therefore marginalised via their lack of visibility) at events held in the church building and by Christian leaders in public space. Many interviewees associated this decision with the missionaries, who often prohibited traditional ceremonial language and discouraged involvement in ceremonial life.

In addition, the Ganggalah Christians integrate practices of "yarning" into the centre of their worship service. "Yarn" is a pan-Aboriginal or "Lingo" word referring to a traditional form of conversing, which is primarily just an "informal and relaxed discussion" (Bessarab and Bridget 2010). However, yarning becomes a tool for meaning-making, particularly for Indigenous participants who gain solidarity in shared urban experiences (Bessarab and Bridget 2010, p. 41). It is also used for self-development as Elders bestow wisdom, and it creates a space of healing as those who suffer deep traumas learn to re-narrate their lives (Atkinson 2002, p. 4). In fact, Aboriginal Australian counsellor Judy Atkinson situates yarning within the Dreaming, as spiritual endeavour:

I will listen to you, share with you, as you listen to, share with me... Our shared experiences are different, but in the inner deep listening to, and quiet, still awareness of each other, we learn and grow together. In this we create community, and our shared knowledge(s) and wisdom are expanded from our communication with each other. (Atkinson 2002, p. 17)

9 Little work has been done on these intersections from a Christian perspective, although this is the subject of a forthcoming edited journal via Australasian Pentecostal Studies.

10 However, although most of the participants enjoyed watching traditional dance and approved of Welcome to Country, only a few tolerated smoking ceremonies, and none would attend a blood ceremony. 
In Indigenous life, yarning creates rapport and accountability within a transformative relationship. Ganggalah participants vocalised the benefits of forming friendships with white Christians in a church context. In particular, they hoped the recent establishment of a denominational Australian Christian Churches (ACC) "Indigenous Initiative" would bring change. The Ganggalah leaders were, through this initiative, helping form institutional links between Aboriginal and non-Aboriginal churches. All interviewees celebrated Welcome (and Acknowledgement) as a practice that may facilitate a successful, equalising dialogue between Indigenous and non-Indigenous Australians in the urban context, something not often present either in society generally—or in urban Australian Pentecostal liturgies. In the task of yarning, participants together discern the Spirit in their world, creating narratives together that amplify Indigenous values and concerns, even within Western institutions (Walker et al. 2013, p. 8). This practice was also considered to reembed the worship into the Australian land.

\section{Intersections between the Metropolis and Heteropolis}

During visits to Sydney, Pastor Will Dumas encouraged church leaders on behalf of their mutual denomination to address Indigenous concerns, and a request was made that Hillsong perform an Acknowledgement of Country at its major conferences, particularly when Aboriginal Christians were attending. This was to become a reality in July 2017 at Australia's premier Christian event, Hillsong Conference, with the performance of the first ever Acknowledgement of Country. The Acknowledgement was spoken live by Jatham Staudinger, an Aboriginal man and staff member from Hillsong Darwin. Standing in front of over 20,000 people, he spoke these words:

"In the beginning, the earth was formless and void. Darkness was upon the bottomless depths.... and the Spirit of God rushed upon the waters."

As the Psalmist says, "When you send your Spirit, you renew the face of the earth."

We are gathered together tonight during our National NAIDOC week on the Country of the Wann-gal people, the traditional custodians who lived and danced by the river.

And Aboriginal people were and are here. We acknowledge the Elders past, present and future.

Now together in many languages, from many lands, we join to worship Jesus, the author and the finisher of our faith, the One who unites all peoples, nations and tongues. ${ }^{11}$

This was followed by a roar in the stadium from the gathered conference attendees. A pre-recorded video with similar words was repeated in 2018 before thousands of attendees at the three Colour conferences for women in March (with this Acknowledgement spoken over the image of Sydney's Harbour Bridge) and was also repeated at Hillsong Conference in July (with the Acknowledgement spoken over footage of green land). At the opening of the new Hillsong campus in Perth, a more traditional Welcome to Country was performed by a local Noongar woman, Frances Ramsey.

In addition, Will Dumas encouraged Hillsong to get their Aboriginal and Torres Strait Islander

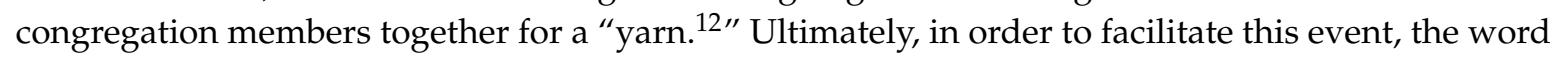
was spread on social media by CityCare and College employees. ${ }^{13}$ who also advertised the event. Pastor Will Dumas attended to facilitate this first yarn (See Figure 1). The conversation was wide reaching, but during this meeting particular comment was made by the group about the effect of the Acknowledgement upon these long-term members.

\footnotetext{
https:/ /hope1032.com.au/stories/faith/2017/aboriginal-australians-acknowledged-hillsong-conference-opening/.

This is an Aboriginal Lingo word which means conversation.

3 Employees such as myself, Jason Allen (CityCare head of department at the time) and Vicky Rough were able to issue invitations to self-identified Aboriginal attendees across the various Sydney campuses, but changes to media law have since changed this process significantly.
} 

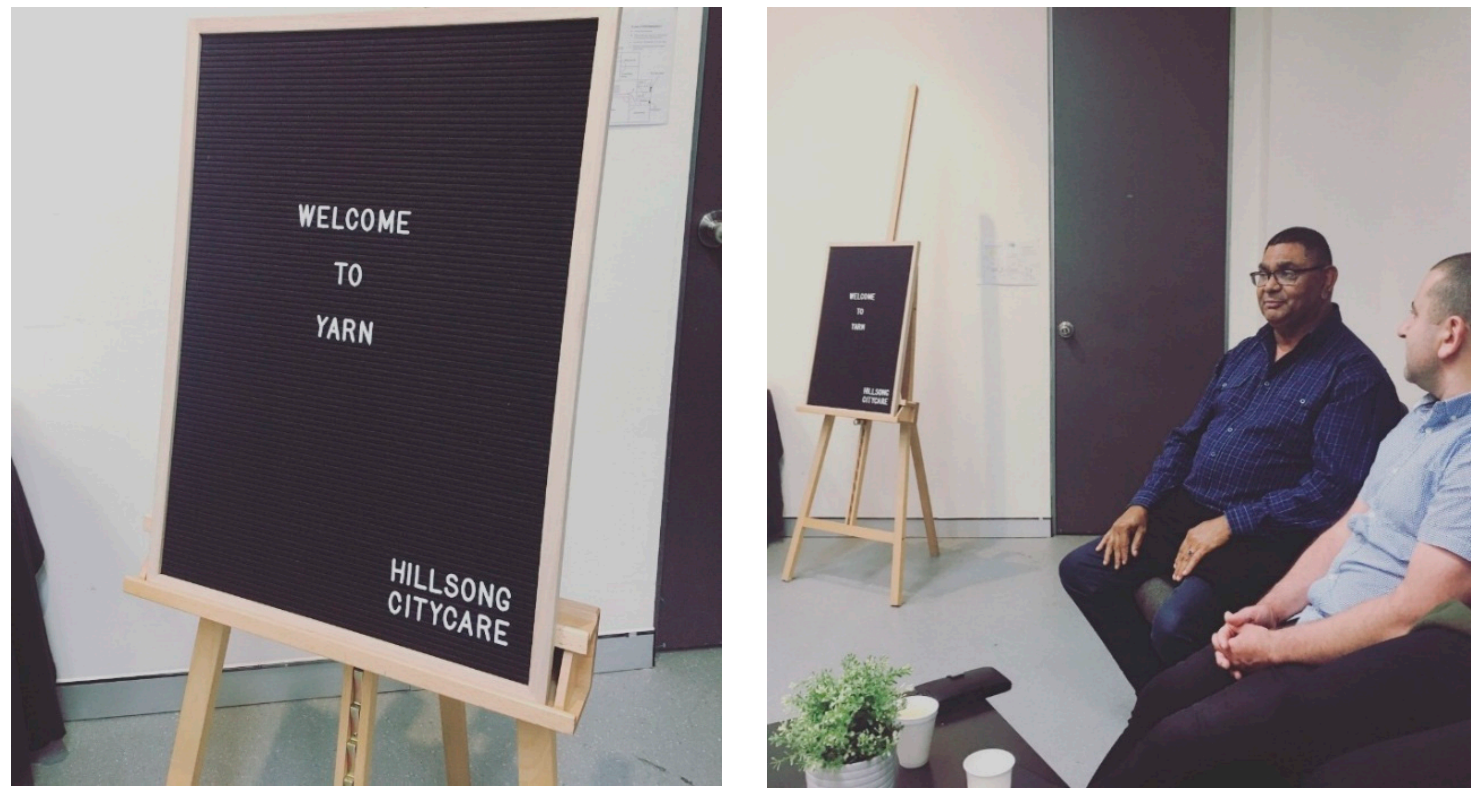

Figure 1. The initial yarning conversation at Hillsong's Waterloo campus.

Many of the group later communicated on Facebook, where I initiated a thread to ask attendees of Hillsong Church about the impact of the 2017 Acknowledgement event upon them. One member of the City campus wrote:

What I loved about the Acknowledgment last year was linking the bible verse about people dancing and celebrating on the land with the connection on lifting up Jesus. Under one name. Something that God is really taking me on a journey through is that intersection, paying respect to culture in faith-filled way.

Some of the Ganggalah Church members also responded, including one who stated that it was "a defining moment in church history. Made me cry tears of joy. It broke down natural and spiritual walls." In addition, non-Indigenous congregation members commented, including one of the African American college students:

The first time I was at conference and witnessed the Acknowledgement to Country [at Hillsong Conference], I cried. It was beautiful. To me it wasn't just church choosing to recognise and honour the people of the land, it was church choosing to see and value them.

Although most believed that this had been a positive move forward for reconciliation, Aboriginal people had varied opinions on how Acknowledgements should be integrated into church practice. A member of the Darwin campus wrote:

In a Christian context, I believe that we Indigenous and other people always need to include the Great I AM, without exception. As that's what our business is about in the first instance.

Others noted that they only really appreciate the ceremonial moment when it is "real," or "happens out of genuine respect." They pointed to the need for reconciliation between Indigenous and non-Indigenous congregation members to overflow from these speech acts. Another stated, "when it becomes part of a bureaucratic checklist it can feel flat." Some noted that spoken Acknowledgement was a colonial appropriation of the more traditional performances that included smoking ceremonies. However, it was clear that the Aboriginal and Torres Strait Islander members of Hillsong had enjoyed greater participation in the church since this speech act had occurred, with leaders understanding who they were and sparking conversations about their traditional lands and cultures. In this way, Hillsong as metropolis had acknowledged the heteropolis in its own congregation in some new ways. 


\section{Discussion: The Charismatic City}

What do these events, and the related responses, show about The Charismatic City? In this article, I aimed to show how Robbins's three impulses at play could possibly operate simultaneously, as illustrated through the interactions of two Pentecostalisms in Australia and the impacts of the interactions upon practice. This investigation drew upon Wariboko's argument for a particular Pentecostal social engagement. His proposal points to the "mystery, openness, and possibilities" found in the Scriptures, as well as the work of the Spirit throughout Christian history, to assert a "Charismatic City" metaphor that represents a new and developing "space wherein, whereby, and whereon believers live, act, and commune with one another." Pentecostalism, Wariboko notes, is at its heart a rhizomatic network of interconnecting free churches. This New Jerusalem can be conceived as the body of Christ. However, also notably, "this space goes beyond the Church as narrowly conceived" (Wariboko 2014, p. 171). He warns,

The body of Christ exceeds the limits of Christian membership. In the era of globalization and the emergence of the global commons, the worldwide body of Christ has become one immense, cosmopolitan city or world city. (Wariboko 2014, p. 169)

He describes a "city where there is openness to the surprises of the Holy Spirit, irruptions of divine energies for communion, and the flourishing of human coexistence (Wariboko 2014, p. 177). Wariboko (2014, p. 171) asserts, "this is ... how the body of Christ is; it is space and places opened up by Jesus of Nazareth." In fact, he terms this a "turn to land" (Wariboko 2014, p. 179). This "enspirited" church is a work in progress, changing and adapting to its other and the context in which it lives. Thus, as Pentecostal congregations interact upon each other, they have capacity to bring Robbins's "world making" and "world breaking" impulses together simultaneously within today's globalising (and secularising) era.

And so, this proposal attempted to demonstrate congregation as process: Rather than a collective of individuals, it is instead seen as a series of events coordinated by practices, media representation, and/or institution (Wariboko 2014, p. 186). The process that Wariboko (2014, p. 177) describes is akin to the polis-a space that facilitates the meeting of strangers, who become aware of each other's needs, and from this, creatively construct a new commons together through shared practices. As communities reappropriate their locally available resources, they form new theologies that assist them to exist differently within their contexts. In this way, the church is the work of the people. The article noted interacting non-Indigenous and Indigenous Pentecostalisms set within the current political and social context of Australia, which arguably demonstrate both a dominant Pentecostal culture "metropolis (mother city) and pre-existing and diverse Pentecostal heteropolis (other, alternative city) ... operating in, through, and energizing global cities" (Wariboko 2014, p. xii). Pentecostalism here offers possibility for a new conception of space or place which is compatible with traditional Australian notions of "country." Thus, the global or universal that is emphasised (perhaps overemphasised) within transnational Christian worship circles such as Hillsong has potential to embed into the land, via acknowledging the continent's traditional peoples, land, and customs. Even as Australian reconciliation is arguably a failed project, each group actively participates in the formation of a transnational, glocal Pentecostal Australian civil society.

Noting the particular intersections between dominant and marginalised forms is important for understanding transnational Pentecostal worship today, as it seeks to act from an understanding of the Spirit at work in the world. As these Australian Pentecostals in the cities engage their "other," both draw upon their own traditions to "refold" what they know in order to speak in new tongues, moving towards greater understanding of each other. The evidence for the congregation as process in Australia, I have posited, is found in the new poetic languages that identify participants and attune them to the Spirit's work, here in the sense of a "metropolis (mother city) and a heteropolis (other, alternative city)" that were previously separated by racial segregation. One example of this new constructive language being outlined is found in the adoption of Acknowledgement of Country, which here serves to confirm 
change within Pentecostal worship rituals and to translate Pentecostal Christianity across time and space. Wariboko (2014, p. 97) describes this as such:

By celebrating the "pluralism" that comes from speaking in many tongues, the movement undercuts heteronomous imposition of any truth for the privilege of consensual, investigative, pragmatic truth by those who autonomously subject themselves to the Spirit of God.

These new speech acts bring the alternative into the main arena, but now empowered with religiously imbued meaning. This serves as representative of a new polis being created.

However, as Pentecostal congregational practices translate into the conference stadium and into the online space, we often do not know who the audience is, or, in other words, who is participating. In regards to Pentecostalism's future trajectories, the resources that now seem most useful for its task of engaging the globe are those which were previously sidelined: The marginal voices representative of the "other," and the liturgy itself; the work of artists and songwriters; and forms of the self (both emotional and feminine) often denied by the theological guild in pursuit of propositional or doctrinal statements. Sometimes, motivation for revision is borne from deep pastoral concern in the metropolis regarding Christianity and its engagement with its now visible "others" in the online and urban environment. The benefit of locating theological research within the work of Pentecostal people is the possibility for recognition of these ever-transforming languages of Spirit empowerment. Such fresh metaphors provide new ways of conceiving the Spirit's actions in the world today.

Funding: This research received no external funding.

Conflicts of Interest: The author of this paper is a part-time employee of Hillsong College, affiliated with Hillsong Church. All views expressed are the author's own and not representative of either organisation.

\section{References}

Australian Bureau of Statistics. 2006. Population Characteristics Aboriginal and Torres Strait Islander Australians. Canberra. Available online: www.abs.gov.au (accessed on 26 November 2015).

Australian Bureau of Statistics. 2011. 1301.0 Year Book Australia: Religious Affliation. Canberra: Australian Bureau of Statistics.

Akehurst, Christopher. 2012. Smoking Out Evil Spirits at the CSIRO. Quadrant Magazine 56: 44-45.

Albrecht, Daniel E. 1999. Rites in the Spirit: A Ritual Approach to Pentecostal/Charismatic Spirituality. Sheffield: Academic Press.

Anderson, Allan. 2010. Varieties, Taxonomies, and Definitions. In Studying Global Pentecostalism: Theories and Methods. Edited by Allan Anderson, Michael Bergunder, Andre F. Droogers and A. Cornelis van der Laan. Berkeley and Los Angeles: University of California Press.

Anderson, Allan. 2013. To the Ends of the Earth: Pentecostalism and the Transformation of World Christianity. Oxford: Oxford University Press.

Atkinson, Judy. 2002. Trauma Trails, Recreating Song Lines: The Transgenerational Effects of Trauma in Indigenous Australia. North Geelong: Spinifex Press.

Bessarab, Dawn, and Ng'andu Bridget. 2010. Yarning About Yarning as a Legitimate Method in Indigenous Research. International Journal of Critical Indigenous Studies 3: 37-50. [CrossRef]

Calley, Malcolm John Chalmers. 1955. Aboriginal Pentecostalism: A Study of Changes in Religion, North Coast. Ph.D. dissertation, University of Sydney, Sydney, NSW, Australia.

Calley, Marie, and Marie Reay. 1964. Aborigines Now: New Perspectives in the Study of Aboriginal Communities. Sydney: Angus and Robertson.

Cartledge, Mark J. 2006. Encountering the Spirit: The Charismatic Tradition. Maryknoll: Orbis Books.

Chesnut, R. Andrew. 1997. Born Again in Brazil: The Pentecostal Boom and the Pathogens of Poverty. New Brunswick: Rutgers University Press.

Coleman, Simon. 2000. The Globalisation of Charismatic Christianity. Cambridge: Cambridge University Press.

Collins, Randall. 2004. Interaction Ritual Chains. Princeton: Princeton University Press.

Connell, John. 2005. Hillsong: A Megachurch in the Sydney Suburbs. Australian Geographer 36: 315-32. [CrossRef] 
Cox, Harvey. 2013. Fire from Heaven: The Rise of Pentecostal Spirituality and the Reshaping of Religion in the 21st Century. New York: Avalon Publishing Group.

Csordas, Thomas J. 1992. Religion and the world system: The pentecostal ethic and the spirit of monopoly capital. Dialectical Anthropology 17: 3-24. [CrossRef]

Csordas, Thomas J. 2007. Introduction: Modalities of transnational transcendence. Anthropological Theory 7: 158-272. [CrossRef]

Dombrowski, Kirk. 2001. Against Culture: Development, Politics, and Religion in Indian Alaska. Lincoln: University of Nebraska Press.

Dombrowski, Kirk. 2002. The Praxis of Indigenism and Alaska Native Timber Politics. American Anthropologist 104: 1062-73. [CrossRef]

Durkheim, Emile. 1912. The Elementary Forms of the Religious Life. New York: Free Press.

Evans, Mark. 2006. Open Up The Doors: Music in the Modern Church. London: Equinox.

Evans, Mark. 2015. Hillsong Abroad: Tracing the Songlines of Contemporary Pentecostal Music. In Spirit of Praise. Edited by Monique M. Ingalls and Amos Yong. University Park: The Penn State University.

Everett, Kristina. 2009. Welcome to Country ... Not. Oceania 79: 53-64. [CrossRef]

Farhadian, Charles E. 2007. Christian Worship Worldwide: Expanding Horizons, Deepening Practices. Grand Rapids: William B. Eerdmans Pub.

Gifford, Paul. 2004. Ghana's New Christianity: Pentecostalism in a Globalizing African Economy. Bloomington: Indiana University Press.

Gifford, Paul. 2015. Christianity, Development and Modernity in Africa. London: C. Hurst Publishers Limited.

Grieves, Vicki. 2008. "The Battlefields": Identity, Authenticity and Aboriginal Knowledges in Australia. In Indigenous Peoples: Self-Determintation, Knowledge, Indigeneity. Edited by Henry Minde. Delft: Eburon Academic Pub.

Grieves, Vicki. 2009. Aboriginal Spirituality: Aboriginal Philosophy, The Basis of Aboriginal Social and Emotional Wellbeing. In Discussion Paper Series: No. 9. Darwin: Cooperative Research Centre for Aboriginal Health.

Held, David, Anthony McGrew, David Goldblatt, and Jonathan Perraton, eds. 1999. Global Transformations: Politics, Economics and Culture. Cambridge: Polity Press.

Hummel, Charles. 1978. Fire in the Fireplace: Contemporary Charismatic Renewal. Downers Grove: InterVarsity Press.

Hutchinson, Mark. 2013. "Without the Holy Spirit, you're stuffed": Pentecostalism as Globalizing Techne. Paper presented at Pentecostalism and Transnationalism Symposium, University of Western Sydney, Sydney, Australia, August 1.

Hutchinson, Mark. 2017. The Problem with 'Waves': Mapping Charismatic Potential in Italian Protestantism 1890-1929. Pneuma 39: 34-54. [CrossRef]

Jennings, Mark Alan Charles. 2017. Great risk for the kingdom: Pentecostal-Charismatic growth churches, pastorpreneurs, and neoliberalism. In Multiculturalism and the Convergence of Faith and Practical Wisdom in Modern Society. Hershey: IGI Global, pp. 236-48.

Langmead, Ross. 2002. Ecomissiology. Missiology 30: 505-18. [CrossRef]

Langmead, Ross. 2007. Reimagining God and Mission: Perspectives from Australia. Adelaide: ATF Press.

Lovett, Leonard. 2015. Black Origins of the Pentecostal Movement. In Aspects of Pentecostal-Charismatic Origins. Flora: Logos International. First published 1975.

McIntyre, Elisha H. 2007. Brand of Choice: Why Hillsong is Winning Sales and Souls. Journal for Academic Study of Religion 2: 175-94. [CrossRef]

Macchia, Frank D. 1993. Tongues as a Sign: Towards a Sacramental Understanding of Pentecostal Experience. The Journal of the Society for Pentecostal Studies 15: 61-76.

Magowan, Fiona. 2000. Dancing with a Difference: Reconfiguring the Poetic Politics of Aboriginal Ritual as National Spectacle. Australian Journal of Anthropology 11: 308-21. [CrossRef]

Marshall-Fratani, Ruth. 1998. Mediating the Global and Local in Nigerian Pentecostalism. Journal of Religion in Africa 28: 278-315. [CrossRef]

Marshall, I. Howard. 1977. The Significance of Pentecost. Scottish Journal of Theology 30: 347-69. [CrossRef]

Marti, Gerardo. 2012. Worship across the Racial Divide: Religious Music and the Multiracial Congregation: Religious Music and the Multiracial Congregation. Oxford: Oxford University Press.

Marti, Gerardo. 2017. The Global Phenomenon of Hillsong Church: An Initial Assessment. Sociology of Religion. 78: 377-86. [CrossRef] 
Maxwell, David. 2005. The Durawall of Faith: Pentecostal Spirituality in Neo-Liberal Zimbabwe. In Indigenous Peoples and Religious Change. Edited by Peggy Brock. Leiden and Boston: Brill, pp. 177-201.

Meyer, Birgit. 2003. Material Mediations and Religious Practices of World-Making. In Religion across Media: From Early Antiquity to Late Modernity. Edited by Peter Lang. New York: Peter Lang, pp. 1-19.

Meyer, Birgit. 2009. From Imagined Communities to Aesthetic Formations: Religious Mediations, Sensational Forms and Styles of Binding. In Aesthetic Formations: Media, Religion and the Senses. New York: Palgrave Macmillan.

Meyer, Birgit. 2010. Pentecostalism and Globalization. In Studying Global Pentecostalism: Theories and Methods. Edited by Allan Anderson, Michael Bergunder, Andre Droogers and Cornelis van der Laan. Berkeley: University of California Press.

Myers, Bryant L. 2015. Progressive Pentecostalism, Development and Christian Development NGOS: A Challenge and an Opportunity. International Bulletin of Missionary Research 39: 115-20. [CrossRef]

Myrick, Nathan. 2017. Relational Power, Music, and Identity: The Emotional Efficacy of Congregational Song. Yale Journal of Music E Religion 3: 5.

Ono, Akiko. 2011. Who Owns the 'De-Aboriginalised' Past? Ethnography meets photography: A case study of Bundjalung Pentecostalism. In Ethnography \& the Production of Anthropological Knowledge: Essays in Honour of Nicolas Peterson. Canberra: ANU E Press.

Ono, Akiko. 2012. You gotta throw away culture once you're Christian: How 'culture' is Redefined among Aboriginal Pentecostal Christians in Rural New South Wales. Oceania 82: 74-85. [CrossRef]

Piot, Charles. 2012. Pentecostal and development imaginaries in West Africa. In Pentecostal and Development: Churches, NGOs and Social Change in Africa. Edited by Dena Freeman. Basingstoke: Palgrave Macmillan.

Poloma, Margaret M., and John C. Green. 2010. The Assemblies of God: Godly Love and the Revitalization of American Pentecostalism. New York: New York University Press.

Porter, Mark. 2017. Singing Beyond Territory: Hillsong and Church Planting in Oxford, UK. In The Hillsong Movement Examined. Edited by Tanya Riches and Tom Wagner. New York: Palgrave Macmillan.

Porter, Mark. 2018. Charismatic Worship and Cosmopolitan Movement(s). Liturgy 33: 4-11. [CrossRef]

Riches, Tanya. 2010a. Shout to the Lord: Music and Change at Hillsong 1996-2007. M.Phil. thesis, Australian Catholic University, Melbourne, Australia.

Riches, Tanya. 2010b. The Evolving Theological Emphasis of Hillsong Worship (1996-2007). Australasian Pentecostal Studies 13: 87-132.

Riches, Tanya. 2014. A Poetics of Interfaith Dialogue in Australia. Evangelical Interfaith Dialogue 5: 28-30.

Riches, Tanya. 2016. Can we still sing the lyrics "Come Holy Spirit?" Spirit and Place in Australian Pentecostalism. Pneuma 38: 274-92. [CrossRef]

Riches, Tanya, and Tom Wagner. 2012. The Evolution of Hillsong Music: From Australian Pentecostal Congregation into Global Brand. Australian Journal of Communication 39: 17-36.

Riches, Tanya, and Tom Wagner. 2017. The Hillsong Movement Examined: You Call Me Out Upon the Waters. New York: Palgrave McMillan.

Riches, Tanya. 2017. (Re)imagining Identity in the Spirit: Worship and Social Engagement in Urban Aboriginal-led Pentecostal Congregations. Ph.D. thesis, Fuller Theological Seminary, Pasadena, CA, USA, January 1.

Robbins, Joel. 2010. Anthropology, Pentecostalism, and the New Paul: Conversion, Event, and Social Transformation. South Atlantic Quarterly 109: 633-52. [CrossRef]

Rose, Lena. 2018. Geometries of 'Global' Evangelicalism. Available online: https:/ / onlinelibrary.wiley.com/doi/ pdf/10.1111/glob.12211 (accessed on 20 September 2018).

Smith, James K. A. 2010. Thinking in Tongues: Pentecostal Contributions to Christian Philosophy. Grand Rapids: B. William Eerdmans Publishing Company.

Solivan, Samuel. 1998. Spirit, Pathos and Liberation: Toward an Hispanic Pentecostal Theology. London: Bloomsbury Academic.

Synan, Vinson. 1993. The Role of Tongues as Initial Evidence. Tulsa: Oral Roberts University, Holy Spirit Research Center.

Trudgen, Richard Ian. 2000. Why Warriors Lie Down and Die. Darwin: Aboriginal Resource \& Development Services Inc.

Wade, Matthew, and Maria Hynes. 2013. Worshipping Bodies: Affective Labour in the Hillsong Church. Geographical Research 51: 173-79. [CrossRef] 
Walker, Melissa, Bronwyn Fredericks, Kyly Mills, and Debra Anderson. 2013. "Yarning" as a method for community-based health research with Indigenous women: The Indigenous women's wellness research project. Health Care for Women International 35: 1216-26. [CrossRef] [PubMed]

Wariboko, Nimi. 2014. The Charismatic City and the Public Resurgence of Religion: A Pentecostal Social Ethics of Cosmopolitan Urban Life. New York: Palgrave Macmillan.

Yong, Amos. 2000. Discerning the Spirit(S): A Pentecostal-Charismatic Contribution to Christian Theology of Religions. Journal of Pentecostal Theology Supplement Series; London: Bloomsbury T\&T Clark, p. 24.

Yong, Amos. 2013. What Spirit(s), Which Public(s)? The Pneumatologies of Global Pentecostal-Charismatic Christianity. International Journal of Public Theology 7: 241-59.

Yong, Amos. 2015. Improvisation, Indigenization, and Inspiration: Theological Reflections on the Sound and Spirit of Global Renewal. In The Spirit of Praise: Music and Worship in Global Pentecostal-Charismatic Christianity. Edited by Monique M. Ingalls and Amos Yong. University Park: The Penn State University Press, pp. 279-88.

(C) 2018 by the author. Licensee MDPI, Basel, Switzerland. This article is an open access article distributed under the terms and conditions of the Creative Commons Attribution (CC BY) license (http://creativecommons.org/licenses/by/4.0/). 